\title{
Analisis Kolaborasi Penelitian Ilmiah Dosen Fakultas X dengan Social Network Analysis (SNA)
}

\author{
Hennie Tuhuteru $^{\# 1}$, Ade Iriani*2 \\ \# Magister Sistem Informasi, Universitas Kristen Satya Wacana \\ Jl. Diponegoro 52-60 Salatiga 50711, Indonesia \\ 1hannytuhuteruegmail.com \\ * Magister Sistem Informasi, Universitas Kristen Satya Wacana \\ Jl. Diponegoro 52-60 Salatiga 50711, Indonesia \\ 2adeiriani@gmail.com \\ Abstract
}

Scientific publications have become the benchmarks of a country's progress in the field of academics. This prompted the Indonesian government to issue a policy, to increase the researcher's interest in collaborating and publicizing their research. Improving quality in research collaboration at college or faculty level could be done by analyzing the research collaboration conducted before. This research aims to understand the pattern of research collaboration, conducted by lecturers of Faculty X in YZ University based on the published scientific papers both locally, nationally and internationally. The method used to analyze the collaboration is Social Network Analysis (SNA). The centralizes measure that we used in SNA are degree centrality, closeness centrality, and betweenness centrality, to know how big the influences of each actor in the network. Additional attributes used to understand collaboration patterns, i.e. Study Program and Academic Functional Position (JAFA). The results of this research are the centrality value of each actor and the mapping of the network pattern based on the centrality and the attributes used. In addition, the relationship between actors is also seen based on the attributes that have been determined to offer more views on the conclusions of this study. It could be concluded that with the measurement in SNA, could be found the pattern of collaboration research from each actor based on the measurements of the social network in the form of sociogram and the result of analysis of each actor in the form of sociometry.

Keywords - Centrality, Research Collaboration, Social Network Analysis, Sociogram, Sociometry.

\begin{abstract}
Abstrak
Publikasi ilmiah telah menjadi tolok ukur kemajuan suatu negara dalam bidang akademik. Hal ini mendorong pemerintah Indonesia mengeluarkan kebijakan untuk meningkatkan minat peneliti dalam berkolaborasi dan mempublikasikan hasil penelitiannya. Meningkatkan mutu dan kualitas dalam kolaborasi penelitian pada perguruan tinggi atau ditingkat fakultas dapat dilakukan dengan analisis kolaborasi penelitian yang dilakukan sebelumnya sehingga rencana penelitian yang akan dilakukan menjadi lebih baik. Penelitian ini bertujuan untuk memahami pola kolaborasi penelitian yang dilakukan oleh dosen Fakultas X di Universitas YZ berdasarkan karya ilmiah yang sudah dipublikasikan baik secara lokal, nasional maupun internasional. Metode yang dipakai menggunakan metode Social Network Analysis (SNA), dengan memanfaatkan 3 pengukuran sentralitas, yaitu degree centrality, closeness centrality, dan betweenness centrality untuk mengetahui seberapa besar pengaruh masing-masing aktor didalam jaringan. Attribut tambahan yang dipakai untuk memahami pola kolaborasi, yaitu Program Studi dan Jabatan Fungsionalis Akademik (JAFA). Hasil dari penelitian ini berupa nilai sentralitas dari masing-masing aktor dan pemetaan pola jaringannya berdasarkan nilai sentralitas dan attribut yang digunakan. Dapat disimpulkan bahwa dengan pengukuran didalam SNA, dapat diketahui pola kolaborasi penelitian dari masing-masing aktor berdasarkan pengukuran pada jaringan sosial berupa sociogram, serta hasil analisis masing-masing aktor yang berupa sociometry.
\end{abstract}

Kata Kunci- Kolaborasi Penelitian, Sentralitas, Social Network Analysis, Sociogram, Sociometry 